\title{
ZAKAT UANG ELEKTRONIK
}

\author{
Badrah Uyuni \\ Universitas Islam As-Syafiiyah \\ badrahuyuni.fai@uia.ac.id
}

\author{
Mohammad Adnan \\ Universitas Islam As Syafi'iyah \\ adnannur@hotmail.com
}

\begin{abstract}
ABSTRAK
Uang elektronik merupakan alat pembayaran yang diterbitkan atas dasar nilai uang yang disetor terlebih dahulu oleh pemegang kepada penerbit, kemudian nilai uang tersebut disimpan secara elektronik dalam suatu media uang elektronik yang digunakan sebagai alat pembayaran oleh pemegang kepada pedagang.

Uang elektronik tersebut dipersamakan dengan uang karena pada saat pemegang menggunakannya sebagai alat pembayaran kepada pedagang, bagi pedagang tersebut nilai uang elektronik berpindah dari media uang elektronik yang dimiliki oleh pemegang ke terminal penampungan nilai uang elektronik milik pedagang. Apapun satuan nilai dalam media uang elektronik tersebut, pada dasarnya berupa nilai uang yang pada waktunya akan ditukarkan kepada penerbit dalam bentuk uang tunai (cash).

Dengan dipersamakannya uang elektronik dengan uang, maka pertukaran antara nilai uang tunai (cash) dengan nilai uang elektronik merupakan pertukaran atau jual beli mata uang sejenis yang dalam literatur Fikih Muamalat dikenal dengan Al-Sharf. Disamping al-shorf terdapat akad-akad lain yang terkait dengan transaksi uang elektronik, diantaranya adalah: al-ijarah, dan wakalah.
\end{abstract}

Kata Kunci : Zakat, Uang elektronik

\section{A. Pendahuluan}

Seiring perkembangan zaman dan teknologi, semakin banyak perubahan yang terjadi dalam kehidupan sehari-hari. Termasuk dalam hal transaksi tukar menukar (keuangan). Begitu dahsyat inovasinya bahkan kebanyakan uang di dunia sekarang ini adalah elektronik, dan uang tunai mulai semakin berkurang penggunaannya. Perubahan gaya hidup juga membuat minat masyarakat terutama milenial zaman now menggunakan uang elektronik untuk transaksi harian semakin meningkat. Dengan perkenalan internet, bank online, kartu debit, dan pembayaran online, dan bisnis internet, uang kertas ataupun alat tukar lainnya yang telah ada terlebih dahulu menjadi sebuah barang masa lalu. Dan dapat dikatakan bahwa saat ini adalah eranya Cashless Society.

Bahkan bank-bank sekarang menawarkan jasa di mana "customer" dapat mentransfer dana, saham yang dibeli, menyumbang ke rencana pensiun mereka dan menawarkan berbagai variasi jasa lainnya tanpa harus menggunakan uang tunai atau cek. Pelanggan tidak harus menunggu barisan, dan ini menciptakan linkungan yang bebas-repot. Kartu debit dan pembayaran online membuat transfer dana secara langsung dari seorang individu ke account 
bisnis, tanpa uang kertas telah memberikan kepraktisan yang besar bagi banyak orang dan juga bisnis.

Bahkan dalam perkembangan industri keuangan syariah. Banyak bank syariah atau lembaga keuangan syariah yang sudah mulai menerbitkan uang elektronik syariah. Dan lagi kebiasaan masyarakat untuk bersedekah dan berzakat pun sudah mulai menggunakan layanan digital. Pembayaran zakat melalui platform online menjadi pilihan baru dalam metode menunaikan zakat

Jika ditelisik lebih jauh, peningkatan transaksi uang elektronik ini karena pertumbuhan transaksi secara online yang tersebar di merchant - merchant offline, e-commerce, maupun transportasi daring.

\section{B. Uang Elektronik Alat Tukar Kontemporer}

Uang elektronik (atau uang digital) adalah uang yang digunakan dalam transaksi Internet dengan cara elektronik. Biasanya, transaksi ini melibatkan penggunaan jaringan komputer (seperti internet dan sistem penyimpanan harga digital). Electronic Funds Transfer (EFT) adalah sebuah contoh uang elektronik. Uang elektronik juga memiliki nilai tersimpan (storedvalue) atau prabayar (prepaid) dimana sejumlah nilai uang disimpan dalam suatu media elektronis yang dimiliki seseorang. Media tersebut dapat berupa server atau chip. ${ }^{1}$

Hingga saat ini, BI mencatat penyelenggara uang elektronik yang mengantongi izin regulator, baik yang berbasis server maupun kartu sebanyak 37 perusahaan

Berikut ini daftar uang elektronik yang sudah terdaftar di Bank Indonesia: ${ }^{2}$

1. PT Artajasa Pembayaran Elektronis (MYNT E-Money)

2. PT Bank Central Asia Tbk (Sakuku dan Flazz)

3. PT Bank CIMB Niaga (Rekening Ponsel)

4. PT Bank DKI (Jakarta One/JakOne dan JakCard)

\footnotetext{
${ }^{1}$ 1. Server Based merupakan Uang Elektronik dengan media penyimpanan berupa server, Uang elektronik jenis ini biasanya berbentuk aplikasi seperti GoPay, OVO serta LinkAja. Sedangkan

2. Chip Based merupakan Uang Elektronik dengan media penyimpanan berupa chip. Uang elektronik jenis ini umumnya berbentuk kartu seperti e-money, flazz, dan brizzi.

2 https://money.kompas.com/read/2019/03/23/063000326/ada-37-uang-elektronik-yang-adadi-indonesia-apa-saja
} 
5. PT Bank Mandiri (Persero) Tbk (Mandiri e-Cash dan Mandiri e-Money)

6. PT Bank Mega Tbk (Mega Virtual dan Mega Cash)

7. PT Bank Negara Indonesia (Persero) Tbk (UnikQu dan TapCash)

8. PT Bank Nationalnobu (Nobu e-Money)

9. PT Bank Permata (BBM Money)

10. PT Bank Rakyat Indonesia (T bank dan Brizzi)

11. PT Finnet Indonesia (FinnChannel)

12. PT Indosat, Tbk (PayPro/Dompetku)

13. PT Nusa Satu Inti Artha (DokuPay)

14. PT Skye Sab Indonesia (Skye Mobile Money dan SkyeCard)

15. PT Telekomunikasi Indonesia, Tbk (Flexy Cash dan iVas Card)

16. PT Telekomunikasi Seluler (T-Cash dan Tap Izy)

17. PT XL Axiata, Tbk (XL Tunai)

18. PT Smartfren Telecom Tbk (Uangku)

19. PT Dompet Anak Bangsa (GoPay)

20. PT Witami Tunai Mandiri (TrueMoney)

21. PT Espay Debit Indonesia Koe (Dana)

22. PT Bank QNB Indonesia Tbk (Dooet)

23. PT BPD Sumsel Babel (BSB Cash)

24. PT Buana Media Teknologi (Gudang Voucher)

25. PT Bimasakti Multi Sinergi (Speed Cash)

26. PT Visionet Internasional (OVO Cash)

27. PT Inti Dunia Sukses (iSaku)

28. PT Veritra Sentosa Internasional (Paytren)

29. PT Solusi Pasti Indonesia (KasPro)

30. PT Bluepay Digital Internasional (Bluepay)

31. PT Ezeelink Indonesia (Ezeelink)

32. PT E2Pay Global Utama (M-Bayar)

33. PT Cakra Ultima Sejahtera (DUWIT)

34. PT Airpay International Indonesia (SOPEEPAY)

35. PT Bank Sinarmas (Simas E-Money)

36. PT Transaksi Artha Gemilang (OttoCash) 


\section{PT Fintek Karya Nusantara (LinkAja)}

Berdasarkan dengan Undang-Undang Uang Elektronik di Indonesia PBI No. 11/12/PBI/2009 Pasal 1 Tentang Uang Elektronik, uang elektronik sebagai instrumen pembayaran memiliki kriteria sebagai berikut:

1. Diterbitkan atas dasar nilai uang yang disetor terlebih dahulu oleh pemegang kepada penerbit;

2. Nilai uang disimpan secara elektronik dalam suatu media seperti server atau chip;

3. Digunakan sebagai alat pembayaran kepada pedagang yang bukan merupakan penerbit uang elektronik tersebut; dan

4. Nilai uang elektronik yang disetor oleh pemegang dan dikelola oleh penerbit bukan merupakan simpanan sebagaimana dimaksud dalam undang-undang yang mengatur mengenai perbankan.

Dan berdasarkan lingkup penyelenggaraannya, Uang Elektronik dibedakan menjadi:

1. Closed loop, yaitu Uang Elektronik yang hanya dapat digunakan sebagai instrumen pembayaran kepada Penyedia Barang dan/atau Jasa yang merupakan Penerbit Uang Elektronik tersebut; dan

2. Open loop, yaitu Uang Elektronik yang dapat digunakan sebagai instrumen pembayaran kepada Penyedia Barang dan/atau Jasa yang bukan merupakan Penerbit Uang Elektronik tersebut.

Selain dapat dibedakan berdasarkan media penyimpanannya, Uang Elektronik dapat dibedakan berdasarkan pencatatan identitas Pengguna, berupa:

1. Unregistered, yaitu Uang Elektronik yang data identitas Penggunanya tidak terdaftar dan tidak tercatat pada Penerbit; dan

2. Registered, yaitu Uang Elektronik yang data identitas Penggunanya terdaftar dan tercatat pada Penerbit. 


\section{Penggunaan uang elektronik sebagai alat pembayaran dapat memberikan manfaat sebagai berikut:}

1. Memberikan kemudahan dan kecepatan dalam melakukan transaksi transaksi pembayaran tanpa perlu membawa uang tunai.

2. Tidak lagi menerima uang kembalian dalam bentuk barang (seperti permen) akibat padagang tidak mempunyai uang kembalian bernilai kecil (receh).

3. Sangat applicable untuk transaksi massal yang nilainya kecil namun frekuensinya tinggi, seperti: transportasi, parkir, tol, fast food, dll.

4. Transaksi lebih cepat, tinggal menempel kartu dan tidak perlu menghitung lembar demi lembar uang.

5. Kita lebih mudah melacak setiap pengeluaran sehingga memudahkan dalam mengelola keuangan.

\section{Resiko Uang Elektronik}

Walapun di satu sisi terdapat beberapa manfaat dari Uang Elektronik, tetapi di sisi lain terdapat risiko yang perlu disikapi dengan kehati-hatian dari para penggunanya, seperti : ${ }^{3}$

1. Risiko uang elektronik hilang dan dapat digunakan oleh pihak lain, karena pada prinsipnya uang elektronik sama seperti uang tunai yang apabila hilang tidak dapat diklaim kepada penerbit.

2. Risiko karena masih kurang pahamnya pengguna dalam menggunakan uang elektronik, seperti pengguna tidak menyadari uang elektronik yang digunakan ditempelkan 2 (dua) kali pada reader untuk suatu transaksi yang sama sehingga nilai uang elektronik berkurang lebih besar dari nilai transaksi.

3. Tidak semua penyedia barang dan jasa dapat menerima transaksi elektronik, apalagi di pedesaan dan pasar tradisional.

3 https://www.bi.go.id/id/edukasi-perlindungan-konsumen/edukasi/produk-dan-jasa-sp/uangelektronik/Pages/default.aspx 


\section{Hukum Muamalah Uang Elektronik.}

Uang elektronik pada dasarnya sama seperti uang biasa karena memiliki fungsi sebagai alat pembayaran atas transaksi jual beli barang. Memang secara fisik tidak ada yang diberikan kepada penjual, tetapi bukan berarti tidak ada nilainya. Sebab uang kertas yang selama ini kita pakaipun sebenarnya tidak ada nilainya. Kalau ada nilainya, tidak sesuai dengan yang tertulis di atasnya. Wujudnya tidak lagi berbentuk fisik, melainkan berupa data digital yang disimpan dalam memori sebuah kartu yang praktis dibawa kemana-mana.

Dalam perspektif syariah hukum uang elektronik adalah halal. Kehalalan ini berlandaskan kaidah; setiap transaksi dalam muamalah pada dasarnya diperbolehkan kecuali jika ada dalil yang mengharamkannya, maka saat itu hukumnya berubah menjadi haram. Faktor lainnya yang menjadi alasan kehalalan uang elektronik adalah, karena adanya tuntutan kebutuhan manusia akan uang elektronik, dan pertimbangan banyaknya kemaslahatan yang ada di dalamnya. Dengan dipersamakannya uang elektronik dengan uang, maka pertukaran antara nilai uang tunai (cash) dengan nilai uang elektronik merupakan pertukaran atau jual beli mata uang sejenis yang dalam literatur Fikih Muamalat dikenal dengan Al-Sharf.

Gaya Hidup serba praktis dan serba cepat sudah menjadi budaya masyarakat "zaman now". Masyarakat tak harus repot-repot membawa uang tunai untuk berbelanja. Uang elektronik telah menggantikan segalanya. Pertumbuhan uang elektronik di masyarakat sendiri sangat pesat belakangan. Maka selanjutnya yang dibutuhkan adalah kebijakan dan penghematan dalam menggunakannya, agar tidak boros \& menyebabkan kerugian di lain hari.

Saat ini beberapa Bank Syariah telah mengeluarkan produk yang terkait dengan uang elektronik. Mereka tidak akan berani meluncurkan produk itu kecuali setelah mendapat dukungan dari otoritas jasa keuangan dan MUI dalam hal ini melalui fatwa Dewan Syariah Nasional. Artinya uang elektronik sudah sah digunakan baik menurut agama maupun Negara.

Majelis Ulama Indonesia (MUI) melalui Dewan Syariah Nasional (DSN) telah menerbitkan fatwa yang bisa dijadikan pedoman bagi masyarakat yang menggunakan uang elektronik syariah. Menurut Fatwa DSN No: 116/DSN-MUI/IX/2017, uang elektronik boleh digunakan dengan mengikuti ketentuan yang ada dalam fatwa tersebut. Hal tersebut sesuai dengan yang diungkapkan oleh pengamat ekonomi syariah Ah Azharuddin Lathif: ${ }^{4}$

Hal-hal yang ditekankan dalam fatwa tersebut adalah

\footnotetext{
${ }^{4}$ Fatwa DSN No: 116/DSN-MUI/IX/2017
} 
1. Akad yang digunakan dalam hubungan hukum antara para pihak yang terlibat dalam penyelenggaraan uang elektronik yaitu akad antara penerbit dengan pemegang uang elektronik adalah akad wadiah atau akad qardh.

Akad yang dapat digunakan penerbit dengan para pihak dalam penyelenggaraan uang elektronik (prinsipal, acquirer, pedagang [merchant], penyelenggara kliring, dan penyelenggara penyelesai akhir) adalah akad ijarah, akad ju'alah, dan akad wakalah bi al-ujrah, dan Akad antara penerbit dengan agen layanan keuangan digital adalah akad ijarah, akad ju'alah, dan akad wakalah bi alujrah.

2. Penyelenggaraan dan penggunaan uang elektronik wajib terhindar dari transaksi yang ribawi, gharar, maysir, tadlis, risywah, israf, dan transaksi atas objek yang haram atau maksiat.

3. Jumlah nominal uang elektronik yang ada pada penerbit harus ditempatkan di bank syariah.

4. Dalam hal kartu yang digunakan sebagai media uang elektronik hilang maka jumlah nominal uang yang ada di penerbit tidak boleh hilang.

Sejalan dengan yang diungkapkan Ahzaruddin, pakar perbankan syariah Dede Abdul Fatah juga mengungkapkan bahwa penggunaan uang elektronik dihalalkan. Ia juga menambahkan bahwa uang elektronik yang tersimpan, tidak boleh digunakan oleh oleh penerbit tanpan seizin pemegang kartu. Menurutnya, penggunaan akad qardh dapat berlaku dengan beberapa ketentuan: Jumlah nominal uang dapat digunakan kapan saja. Penerbit boleh menginvestasikannya dan wajib mengembalikannya jumlah pokok kapan saja sesuai kesepakatan. Uang elektronik syariah juga harus sesuai prinsip syariah menggunakan akad wadi'ah (titipan) dan qard (pinjaman kebajikan) antara penerbit dan pemegang.

\section{Prinsip-prinsip Syariah dalam Transaksi Uang Elektronik}

1. Tidak Mengandung Maysir (unsur perjudian, untung-untungan atau spekulatif yang tinggi). Penyelenggaraan uang elektronik harus didasarkan oleh adanya kebutuhan transaksi pembayaran ritail yang menuntut transaksi secara lebih cepat dan efisien, tidak untuk transaksi yang mengandung maysir. 
2. Tidak Menimbulkan Riba yang berbentuk pengambilan tambahan, baik dalam transaksi jual-beli maupun pinjam-meminjam dan pengalihan harta secara batil. Transaksi uang elektronik merupakan transaksi tukar-menukar/jual beli barang ribawi, yaitu antara nilai uang tunai dengan nilai uang elektronik dalam bentuk Rupiah.

3. Pertukaran antara nilai uang tunai dengan nilai uang elektronik harus sama jumlahnya (tamatsul) baik kualitas maupun kuantitasnya, jika tidak, maka tergolong ke dalam bentuk riba al-fadl (tambahan atas salah satu dua barang yang dipertukarkan dalam pertukaran barang Ribawi yang sejenis. Oleh karena itu, tidak boleh melakukan pertukaran nilai uang tunai yang lebih kecil atau lebih besar dari nilai uang elektronik.

4. Pertukaran antara nilai uang tunai dengan nilai uang elektronik harus sama jumlahnya (tamatsul) baik kualitas maupun kuantitasnya, jika tidak, maka tergolong ke dalam bentuk riba al-fadl (tambahan atas salah satu dua barang yang dipertukarkan dalam pertukaran barang Ribawi yang sejenis. ${ }^{5}$ Oleh karena itu, tidak boleh melakukan pertukaran nilai uang tunai yang lebih kecil atau lebih besar dari nilai uang elektronik. Dan pertukaran antara nilai uang tunai dengan nilai uang elektronik harus dilakukan secara tunai (taqabudh), jika tidak, maka tergolong ke dalam bentuk riba al-nasiah (penundaan penyerahan salah satu dua barang yang dipertukarkan dalam jual-beli barang ribawiyang sejenis). ${ }^{6}$

5. Tidak Mendorong Israf (Pengeluaran yang Berlebihan) Uang elektronik pada dasarnya digunakan sebagai alat pembayaran ritail/mikro, agar terhindar dari Israf(pengeluaran yang berlebihan) dalam konsumsi dilakukan pembatasan jumlah nilai uang elektronik serta batas paling banyak total nilai transaksi uang elektronik dalam periode tertentu.

6. Tidak Digunakan untuk Transaksi objek Haram dan Maksiat Uang elektronik sebagai alat pembayaran dengan menggunakan prinsip Syariah, uang elektronik tidak boleh digunakan untuk pembayaran transaksi objek haram dan maksiat, yaitu barang atau fasilitas yang dilarang dimanfaatkan atau digunakan menurut hukum Islam.

\footnotetext{
${ }^{5}$ Sebagai contoh penerbit tidak boleh menjual uang elektronik sebesar Rp 3.000.000,00 dengan penyetoran uang/dana dari pemegang kepada penerbit sebesar Rp 3.030.000,00 dan penerbit juga tidak boleh memberikan potongan harga atas penjualan uang elektronik, seperti uang elektronik dengan nilai uang elektronik sebesar Rp 3.000.000,00 dijual oleh penerbit melalui penyetoran uang/dana dari pemegang kepada penerbit sebesar Rp 2.970.000,00, kelebihan pembayaran oleh pemegang dan potongan harga oleh penerbit tersebut termasuk riba alfadl.

${ }^{6}$ Sebagai contoh pada saat pemegang atau pedagang menukarkan kembali (refund/redeem) nilai uang elektronik dengan nilai uang tunai kepada penerbit, maka penerbit harus memenuhi hak tagih tersebut dengan tepat waktu tanpa melakukan penangguhan pembayaran.
} 
Menurut Fatwa DSN No: 116/DSN-MUI/IX/2017) uang elektronik boleh digunakan dengan mengikuti ketentuan yang ada dalam fatwa tersebut.

1. Terhindar dari transaksi yang dilarang.

2. Biaya layanan fasilitas adalah biaya riil sesuai dengan prinsip ganti rugi / ijarah

3. Dana ditempatkan di bank syariah. Selanjutnya, dalam hal kartu e-money hilang, jumlah nominal uang yang ada di penerbit tidak boleh hilang.

Tidak Mendorong Israf (Pengeluaran yang Berlebihan) Uang elektronik pada dasarnya digunakan sebagai alat pembayaran ritail/mikro, agar terhindar dari Israf(pengeluaran yang berlebihan) dalam konsumsi dilakukan pembatasan jumlah nilai uang elektronik serta batas paling banyak total nilai transaksi uang elektronik dalam periode tertentu.

\section{E. Akad-akad Syariah Terkait Uang Elektronik.}

Uang elektronik merupakan alat pembayaran yang diterbitkan atas dasar nilai uang yang disetor terlebih dahulu oleh pemegang kepada penerbit, kemudian nilai uang tersebut disimpan secara elektronik dalam suatu media uang elektronik yang digunakan sebagai alat pembayaran oleh pemegang kepada pedagang.

Uang elektronik tersebut dipersamakan dengan uang karena pada saat pemegang menggunakannya sebagai alat pembayaran kepada pedagang, bagi pedagang tersebut nilai uang elektronik berpindah dari media uang elektronik yang dimiliki oleh pemegang ke terminal penampungan nilai uang elektronik milik pedagang. Apapun satuan nilai dalam media uang elektronik tersebut, pada dasarnya berupa nilai uang yang pada waktunya akan ditukarkan kepada penerbit dalam bentuk uang tunai (cash).

Dengan dipersamakannya uang elektronik dengan uang, maka pertukaran antara nilai uang tunai (cash) dengan nilai uang elektronik merupakan pertukaran atau jual beli mata uang sejenis yang dalam literatur Fikih Muamalat dikenal dengan Al-Sharf. Disamping al-shorf terdapat akad-akad lain yang terkait dengan transaksi uang elektronik, diantaranya adalah : al-ijarah, dan wakalah.

Secara umum jual beli mata uang (Sharf) diidentikkan dengan tukar menukar antara emas dan emas dan perak dengan perak atau emas dengan perak. Dengan demikian, yang menjadi syaratsyarat dalam transaksi tukar menukar emas dengan emas dan perak dengan perak atau emas dengan perak tersebut berlaku juga dalam transaksi jual beli mata uang. Syarat-syarat 
tersebut adalah; tunai, jumlahnya sama, tidak boleh ada khiyar syarat, dan tidak boleh ditangguhkan.

\section{Relevansi akad Sharf dalam implementasi uang elektronik dapat dilihat pada syarat- syarat akad berikut ini :}

\section{Syarat akad tunai (Al-Taqabudh)}

Nilai uang elektronik yang berada di tangan pemegang sepenuhnya berada dalam kekuasaan pemegang. Dana float yang terkumpul di penerbit bukan merupakan simpanan sebagaimana yang diatur dalam Undang-Undang tentang Perbankan dan sepenuhnya berada dalam penguasaan.

\section{Syarat al-tamatsul (jumlahnya sama)}

Nilai satu Rupiah pada nilai uang elektronik harus sama dengan satu Rupiah pada uang tunai (cash).

\section{Syarat tidak boleh ada Khiyar Syarat}

Dalam transaksi uang elektronik tidak terdapat Khiyar Syarat, pada saat transaksi dilakukan, ketika masing-masing pihak telah menunaikan kewajiban dan mendapatkan haknya, maka transaksi telah selesai.

\section{Syarat tidak boleh ditangguhkan}

Pada saat proses penerbitan, ketika pihak pemegang menyetorkan uang, maka penerbit saat itu juga menyerahkan nilai uang elektronik kepada pemegang dan pada saat terjadi redeem baik oleh pemegang atau oleh pedagang, penerbit harus dapat menunaikannya secara tepat waktu.

\section{Akad-akad Lain yang Terkait dengan uang elektronik.}

Melihat dari relevansi tersebut di atas, maka jelaslah bahwa akad utama yang digunakan dalam penyelenggaraan uang elektronik adalah akad Sharf, yaitu tukar-menukar atau jual beli uang. Namun dalam implementasinya, penyelenggaraan uang elektronik dapat dilengkapi oleh akadakad lain, yaitu:

\section{Akad Ijarah}

Ijarah adalah transaksi sewa menyewa atas suatu barang dan atau upah mengupah atas suatu jasa dalam waktu tertentu melalui pembayaran sewa atau imbalan jasa. Akad Ijarah 
digunakan dalam hal terdapat transaksi sewa menyewa atas perlengkapan/peralatan dan atau terdapat pelayanan jasa dalam penyelenggaraan uang elektronik.

\section{Akad Wakalah}

Wakalah adalah pemberian kuasa kepada orang lain untuk bertindak sebagai pemberi kuasa dalam transaksi yang diperbolehkan dan diketahui. Akad Wakalah digunakan dalam hal penerbit bekerjasama dengan pihak lain sebagai agen penerbit dan/atau terdapat bentuk perwakilan lain dalam transaksi uang elektronik.

\section{F. Zakat Uang Elektronik}

Pada prinsipnya ketika kita menggunakan kertas-kertas itu, kita tidak membayar dengan fisik kertasnya, melainkan dengan nilai yang angkanya dituangkan di atas kertas itu. Maka yang kita bayarkan tetap nilai harga yang memang tidak diwujudkan oleh kertas. Begitu juga ketika kita menggunakan e-money, yang kita bayarkan adalah nilainya meski tanpa wujud fisik. Namun secara teknis, pembayaran itu dilakukan lewat proses data digital.

Di sisi lain, Zakat online sendiri adalah proses pembayaran zakat yang dilakukan melalui sistem digital, di mana pemberi zakat tidak bertemu langsung dengan amil zakat dalam melakukan pembayaran zakat. Amil zakat adalah pihak yang bertanggungjawab terkait pengumpulan hingga penyaluran harta zakat. Cara ini muncul sebagai bentuk adaptasi pada perkembangan zaman di mana masyarakat menginginkan kemudahan lewat bantuan teknologi.

Secara mиamallah, pembayaran zakat berbeda dengan transaksi jual beli yang mewajibkan akad dan ijab qabul. Selama ada muzakki, harta yang akan dizakatkan, serta penerima zakat, pembayaran zakat secara online dalam Islam diperbolehkan selama tidak mengundang mudharat,"

Persoalan kebiasaan ijab qabul dan doa yang biasanya dibacakan oleh amil zakat pun sebetulnya sudah teratasi. Di Rumah Zakat, setiap pembayaran zakat yang cashless akan selalu diikuti oleh konfirmasi melalui SMS untuk meyakinkan niatan muzakki dalam 
berzakat, juga disertai doa yang biasanya dibacakan amil zakat kepada muzakki. Tapi sekali lagi, proses ijab qabul dalam pembayaran zakat tidak diwajibkan,"

Seorang muslim yang mampu secara ekonomi wajib menyisihkan sebagian harta yang dimiliki untuk diberikan kepada orang-orang yang berhak menerimanya, baik melalui panitia zakat maupun didistribusikan sendiri. Hukum zakat adalah wajib bila mampu secara finansial dan telah mencapai batas minimal bayar zakat atau nisab. Nisab adalah batas terendah yang telah ditetapkan secara syar'i yang menjadi pedoman untuk menentukan kewajiban mengeluarkan zakat bagi yang memiliki harta dan telah mencapai ukuran tersebut.

disebutkan. Di antara syarat tersebut adalah penghasilan tersebut telah mencapai nishob dan telah haul (masa satu tahun). Yang jadi patokan adalah nishob perak sebagaimana penjelasan dalam nishob mata uang.

Namun perlu dipahami bahwa pekerja itu ada dua kondisi dilihat dari penghasilannya (gajinya):

Pertama: Orang yang menghabiskan seluruh gajinya (setiap bulan) untuk memenuhi kebutuhannya dan tidak ada sedikit pun harta yang disimpan. Kondisi semacam ini tidak ada zakat.

Kedua: Pekerja yang mampu menyisihkan harta simpanan setiap bulannya, kadang harta tersebut bertambah dan kadang berkurang. Kondisi semacam ini wajib dikenai zakat jika telah memenuhi nishob dan mencapai haul.

Uang simpanan dikeluarkan zakatnya dikarenakan, dari sifat hartanya uang simpanan termasuk ke dalam 3 kriteria harta atau maal, yaitu:

1. Uang simpanan mempunyai nilai ekonomi yaitu nilai tukar.

2. Uang simpanan disukai semua orang bahkan banyak yang memerlukannya.

3. Uang simpanan yang dizakati adalah yang dibenarkan pemanfatannya secara syar'i.

Bahkan karena uang simpanan itu merupakan surplus maka lebih layak dikenakan zakat dibandingkan dengan hasil penghasilan yang bisa jadi surplus bisa juga tidak.

Ketentuan zakat Deposito : 
a. Penghitungan zakat deposito, pendekatannya adalah dengan zakat peniagaan, karena seseorang yang menyimpan uangnya sebagai deposito atau saham sudah berniat untuk mendapatkan keuntungan. Dan niat mendapatkan keuntungan adalah salah satu syarat dalam zakat perniagaan.

lembaga zakat yang mengatakan tidak ada lagi zakat untuk uang tabungan melandaskan ijtihadnya dengan logika bahwa zakat tidak perlu dibayarkan dua kali untuk harta yang sama. Karena pemilik uang sudah bayar zakat penghasilan, maka uang itu tidak perlu lagi dibayarkan zakatnya sebagai zakat tabungan.

Perbedaan pandangan itu biasanya lahir karena berbagai sebab. Yang utama di antaranya karena perbedaan sudut pandang, juga karena perbedaan metodologi pengambilan kesimpulan hukum, bahkan tidak jarang perbedaan itu terjadi karena perbedaan dalam menetapkan keshahihan suatu hadits, juga ketika menetapkan kekhususan dan keumumannya.

Yang mengatakan harus ada zakat tabungan lagi di luar zakat penghasilan berangkat dari logika bahwa tiap jenis harta zakat ada ketentuan zakatnya.

Rumus Perhitungan Zakat Profesi/Pekerjaan

Ada 3 cara menghitung zakat profesi/pekerjaan:

1. Diqiaskan dengan zakat uang sepenuhnya,

2. Diqiaskan dengan zakat hasil tani sepenuhnya,

3. Memakai qias kemiripan dengan zakat uang dan hasil tani.

Zakat maal berlaku untuk harta kekayaan yang dimiliki seorang muslim dengan rumusan sebagai berikut:

Zakat Maal $=2,5 \% \mathrm{X}$ Jumlah harta yang tersimpan selama 1 tahun

Mata uang wajib dizakati karena fungsinya sebagai alat tukar sebagaimana emas dan perak yang ia gantikan fungsinya saat ini. Hukum mata uang ini pun sama dengan hukum emas dan perak karena kaedah yang telah ma'ruf "al badl lahu hukmul mubdal” (pengganti memiliki hukum yang sama dengan yang digantikan).

Mata uang yang satu dan lainnya bisa saling digabungkan untuk menyempurnakan nishob karena masih dalam satu jenis walau ada berbagai macam mata uang dari berbagai negara. 
patokan dalam nishob mata uang adalah nishob emas atau perak. Jika mencapai salah satu nishob dari keduanya, maka ada zakat. Jika kurang dari itu, maka tidak ada zakat. Jika kita perhatikan yang paling sedikit nishobnya ketika ditukar ke mata uang adalah nishob perak. Patokan nishob inilah yang lebih hati-hati dan lebih menyenangkan orang miskin. Besaran zakat mata uang adalah 2,5\% atau 1/40 ketika telah mencapai haul.

dalam hukum fiqih, keberadaan koin emas dan perak masuk ke dalam inti hukum fiqih muamalah.

\section{Referensi}

1.https://id.m.wikipedia.org/wiki/Uang_elektronik

2. Peraturan Bank Indonesia (PBI) No. 20/6/PBI/2018 tentang Uang Elektronik

3. PBI No. 11/12/PBI/2009 Pasal 1 Tentang Uang Elektronik

4. https://www.bi.go.id/id/edukasi-perlindungan-konsumen/edukasi/produk-dan-jasa-sp/uangelektronik/Pages/default.aspx

5. https://money.kompas.com/read/2019/03/23/063000326/ada-37-uang-elektronik-yang-adadi-indonesia-apa-saja

6. data Bank Indonesia menunjukkan transaksi uang elektronik hingga Juni 2019 mencapai Rp 11,87 triliun. Angka ini naik drastis sebesar 242 persen dibandingkan periode yang sama tahun lalu sebesar Rp 3,46 Triliun. 